\title{
Seedlings of Garcinia brasiliensis (Clusiaceae) subjected to root flooding: Physiological, morphoanatomical, and antioxidant responses to the stress
}

\author{
Thiago Corrêa de Souza ${ }^{a, *}$, Elma dos Santos Souza ${ }^{b}$, Sara Dousseau ${ }^{a}$, \\ Evaristo Mauro de Castro ${ }^{\mathrm{a}}$, Paulo César Magalhães ${ }^{\mathrm{c}}$ \\ a Plant Physiology Section, Biology Department, Federal University of Lavras, Campus Universitário, P.O. Box 37, 37200-000 Lavras, MG, Brazil \\ b Phytotechnology Department, Federal University of Viçosa, 36570-000 Viçosa, MG, Brazil

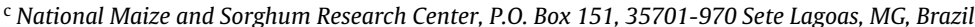

\section{A R T I C L E I N F O}

\section{Article history:}

Received 8 August 2012

Received in revised form 27 August 2013

Accepted 29 August 2013

Available online $\mathrm{xxx}$

\section{Keywords:}

Rheedia brasiliensis

Hypoxia

Root anatomy

Root morphology

WinRhizo

Starch

\begin{abstract}
A B S T R A C T
Garcinia brasiliensis (Mart.) is a native Amazonian tree cultivated throughout Brazil. This plant can tolerate flooding or submergence for several days, during certain periods of the year. The morphophysiological changes of G. brasiliensis (Mart.) seedlings were assessed that may favor their survival in flooded environments. Seedlings with six fully expanded leaves were placed in tanks so that their roots were submerged for 90 days. Antioxidant enzymatic activity and the contents of $\mathrm{H}_{2} \mathrm{O}_{2}$, soluble sugar, starch, and amino acid of the roots were evaluated on six harvesting occasions. At the end of the experiment, the dry mass and root morphology of the seedlings were determined. Flooding lead to a decrease in dry mass of roots and aboveground parts, as well as root length (58\%), surface area (51\%) and volume (43\%), especially of roots with smaller diameter. The roots of the flooded seedlings presented thicker exodermis and greater xylem number, thicker phloem and fewer xylem fibers. There was a small amount of aerenchyma in the roots and hypertrophied lenticels were detected at the base of the stem. Superoxide dismutase activity was significantly higher in flooded roots at all harvesting times, and ascorbate peroxidase and catalase activities were highest during the last two harvestings. $\mathrm{H}_{2} \mathrm{O}_{2}$ content increased after 40 and 55 days of flooding, followed by a drastic decrease. After 70 and 90 days of flooding there was an expressive increase in soluble sugars, and at 90 days, a reduction in starch content. No differences were observed in amino acid content.
\end{abstract}

(c) 2013 Elsevier B.V. All rights reserved.

\section{Introduction}

Garcinia brasiliensis (Mart.), is native to the Amazon region but is cultivated throughout Brazil. A number of phytochemical studies have confirmed the medicinal potential of this plant (Martins et al., 2008; Gontijo et al., 2012).

G. brasiliensis is an evergreen species and can tolerate long periods of flooding or submergence (Duarte et al., 2005). Although there are a lot of researches being carried out concerning morphopysiological adaptation of plants under flooding (Armstrong et al., 1994; Jackson et al., 2009) very few work has been done with G. brasiliensis. Oliveira-Wittmann (2007) reported an increase in the quantity of tocochromanol (vitamin E) in the latex and leaves of this tree. Parolin (2009) reported changes in the submerged leaves,

\footnotetext{
* Corresponding author. Tel.: +55 3538291 612; fax: +55 3538291367.

E-mail addresses: thiagonepre@hotmail.com (T.C. de Souza), souzaelma@hotmail.com (E.d.S. Souza),saradousseau@yahoo.com.br (S. Dousseau), emcastro@ufla.br (E.M. de Castro), paulo.magalhaes@embrapa.br (P.C. Magalhães).
}

including an increase in the size of stomata and the presence of thick epidermal walls (typical of xeromorphic plants).

Flooding represents a situation of excess water in the root zone (Colmer and Voesenek, 2009). Under non-flooding conditions, the root system is in direct contact with oxygen. The decrease of oxygen in the soil due to the excess of water results in hypoxia (low oxygen concentration) or anoxia (absence of oxygen) (BaileySerres et al., 2012). The low level of oxygen in the rhizosphere caused by flooding is one of the major abiotic stresses that can lead to a decrease in the productivity of plants (Jackson and Colmer, 2005).

Root growth is inhibited under stress conditions caused by hypoxia (Armstrong et al., 1991). Under flooding conditions, roots can only grow near the soil surface and cannot totally explore the soil volume. Without oxygen in the roots, energy production is restricted to fermentation, which yields only two ATPs (Sairam et al., 2008). Additionally, hypoxia decreases hydraulic conductivity and affects the aquaporins, diminishing absorption of water and nutrients by roots (Dell'Amico et al., 2001; Tournaire-Roux et al., 2003; Horchani et al., 2008). 
Under hypoxia or anoxia, reactive oxygen species (ROS) are formed. They can cause damage to cell metabolism by oxidizing proteins and lipids (Moller et al., 2007). Plant tissues use both nonenzymatic and enzyme systems (Mitler, 2002; Karuppanapandian et al., 2011), to control ROS levels and protect their cells.

Plants adapted to flooding conditions, such as those found in the Amazon region, modify their morphology, anatomy, and cell metabolisms to survive these unfavorable conditions (De Simone et al., 2003; Parolin, 2009; Oliveira and Joly, 2010). The present work was designed to characterize physiological and morphoanatomical adaptations of Amazonian plants to flooding conditions and to aid in screening processes to select plants for revegetation of riparian zones of artificial reservoirs (formed during the construction and operation of hydroelectric plants). This revegetation can avoid the silting-up caused by erosion. This way, understanding the physiological characteristics of species, whose natural habitats are marked by conditions similar to those observed at the edges of hydroelectric reservoirs (with periodic inundations) will be of significant importance in protecting these sites (Silva et al., 2001). Our hypothesis was that G. brasiliensis seedlings survive for longer periods of flooding, this surviving occurs due to anatomical and metabolic modifications in the roots.

\section{Materials and methods}

\subsection{Plant material, growth conditions, treatments and experiment design}

The fruits of $G$. brasiliensis were harvested from trees growing on the Retiro Farm in the municipality of Campo Formoso, state of Bahia, Brazil $\left(10^{\circ} 30^{\prime} \mathrm{S}\right.$ and $\left.40^{\circ} 19^{\prime} \mathrm{W}\right)$ and were taken to the Plant Growth and Development Laboratory of the Plant Physiology Sector of the Federal University at Lavras, Lavras, MG. The seeds were isolated from the fruits, washed with running water and subsequently germinated on moist Germitest ${ }^{\circledR}$ paper in a BOD incubator at $30^{\circ} \mathrm{C}$ under a 12 -h photoperiod. After germinating, the seedlings were transferred to plastic bags (one plant per bag) containing soil (B horizon) and sand in the proportion of 3:1. Based on soil analysis, the following substances were incorporated into the substrate: potassium chloride $\left(2.5 \mathrm{~kg} \mathrm{~m}^{-3}\right)$, simple super phosphate fertilizer $\left(5 \mathrm{~kg} \mathrm{~m}^{-3}\right)$, ammonium sulfate $\left(725 \mathrm{~g} \mathrm{~m}^{-3}\right)$, and dolomite limestone powder $\left(500 \mathrm{~g} \mathrm{~m}^{-3}\right)$. Sixty days after germination (DAG) the bags containing seedlings with six totally expanded leaves were placed outdoors into brick tanks $(4 \mathrm{~m} \times 1 \mathrm{~m}$ and $0.8 \mathrm{~m}$ deep) and exposed to two conditions: flooded and non-flooded (control).

In the flooded treatment, the water level in the tank was maintained $2 \mathrm{~cm}$ above the level of the soil in the plant bags throughout the experiment, totally covering the roots with water. Under nonflooded conditions, the plants were watered on a daily basis. The treatment and control tanks were covered with a black screen that reduced solar radiation by $70 \%$. The average relative humidity of the air in the tanks throughout the experiment was $75 \%$ and the average maximum and minimum temperatures were $32^{\circ} \mathrm{C}$ and $24^{\circ} \mathrm{C}$, respectively. Evaluations were initiated eight days after the imposition of the flooding regime and undertaken thereafter on the 16th, 40th, 55th, 70th, and 90th days of the experiment. We evaluated the antioxidant enzymatic activity and the content of $\mathrm{H}_{2} \mathrm{O}_{2}$, soluble sugars, starch, and amino acids. Additional parameters were analyzed at the end of the experiment (after 90 days of flooding). The experimental design was completely randomized with ten replicates per treatment.

\subsection{Physiological responses}

Total soluble sugars and amino acids were determined using the same supernatant used in the analyses of antioxidant enzymes. Total soluble sugars was determined by the colorimetric reaction with anthrone at $640 \mathrm{~nm}$, using a glucose standard curve as described by Yemm and Willis (1954). The ninhydrin method was used to quantify amino acids following Yemm and Cocking (1954), using a standard glycine curve. Starch was hydrolyzed using $35 \%$ perchloric acid and quantified using Somogyi method, modified by Nelson (1944).

\subsection{Morphoanatomical responses}

The plants in each sack were harvested, and then washed and separated into root and shoot (leaves + stems). The characteristics of roots were determined using WinRhizo Pro 2007a image analysis system (Regent Instruments, Sainte-Foy, QC, Canada) coupled to a professional scanner (Epson, Expression 10,000 XL, Epson America, Inc., USA) equipped with an additional light unit (TPU). Images of root morphology were obtained by scanning the roots at $400 \mathrm{dpi}$ (Bouma et al., 2000) in an acrylic box $(20 \mathrm{~cm} \times 30 \mathrm{~cm})$ with a film of water of approximately $1-\mathrm{cm}$ thick. The following characteristics were determined: root length $(\mathrm{cm})$, root superficial area $\left(\mathrm{cm}^{2}\right)$, root volume $\left(\mathrm{cm}^{3}\right)$, root medium diameter $(\mathrm{mm})$, and the number of root tips. Root length, volume, and surface area were also classified by diameter class $(0-4.5 \mathrm{~mm})$ using the same software. The plant material was placed into paper bags and dried to constant weight in a forced-air circulation oven at $72{ }^{\circ} \mathrm{C}$, and the following dry weight attributes were evaluated: root dry mass, stem dry mass, leaf dry mass, shoot dry mass (leaves + stem), and root/shoot ratio (relationship between root dry mass and shoot dry mass). Other attributes of the morphological and dry mass data were calculated, including: specific root length $\left(\mathrm{mm} \mathrm{g}^{-1}\right)$, root fineness $\left(\mathrm{mm} \mathrm{mm}^{-3}\right)$, and root tissue density $\left(\mathrm{g} \mathrm{mm}^{-3}\right)$.

For root anatomy study, two complete roots per plant (including the apical, elongation, piliferous, and basal regions) were randomly harvested from each replication and washed in running water. The roots were then fixed in formaldehyde, acetic acid, and 70\% ethanol solution (FAA 70) for $48 \mathrm{~h}$ and subsequently preserved in $70 \%$ ethanol. Transverse sections were cut $2 \pm 0.5 \mathrm{~cm}$ from the root apex using a table-mounted microtome. The sections were cleared with $5 \%$ sodium hypochlorite for $10 \mathrm{~min}$, rehydrated for $10 \mathrm{~min}$, stained with Astrablau (safranine and Astra blue, 7.5:2.5), and subsequently mounted on slides in $50 \%$ glycerin. The sections were photographed with an Olympus BX-60 light microscope coupled to a digital camera. The resulting photomicrographs were used to measure the following parameters: cortex width, exodermis width, proportion of aerenchyma in the cortex, phloem width, xylem vessel number, and xylem fibers area. The proportion of aerenchyma in the cortex was calculated by dividing total aerenchyma area by total cortex area.

These measurements were made using image analysis software (UTHSCSA ImageTool, University of Texas Health Science Center at San Antonio, San Antonio, TX, USA), based on calibrations made with a microscope ruler photographed at the same magnification as the photomicrographs. The mean of five measurements was used for each anatomical character.

\subsection{Antioxidant responses}

Enzyme extracts were prepared by macerating $250 \mathrm{mg}$ of root material in liquid nitrogen and adding $1.5 \mathrm{~mL}$ of an extraction buffer (100 mM potassium phosphate buffer, pH 7.0, 1 mM EDTA, $2 \mathrm{mM}$ DTT, $0.8 \mathrm{mM}$ PMSF, $1 \%$ PVPP, and $1 \mathrm{mM}$ ascorbic acid). The extracts were centrifuged at $14,000 \mathrm{rpm}$ for $30 \mathrm{~min}$ at $4{ }^{\circ} \mathrm{C}$ and the 





* Indicates statistically significant results at $p \leq 0.05$.

supernatants collected and stored at $-80^{\circ} \mathrm{C}$ until the time of enzyme analysis. Enzyme activity was expressed as milligrams ( $\mathrm{mg}$ ) of protein, as determined by the Bradford method (1976) using bovine serum albumin (BSA) as the standard.

Superoxide dismutase activity (SOD, EC 1.15.1.1) was evaluated by its capacity to inhibit the photoreduction of nitro blue tetrazolium (NBT), as proposed by Giannopolitis and Ries (1977). The reaction mixture was composed of $100 \mu \mathrm{L}$ enzyme extract and $1.9 \mathrm{~mL}$ reaction medium (containing $50 \mathrm{mM}$ potassium phosphate buffer $\mathrm{pH}$ 7.8, $14 \mathrm{mM}$ methionine, $0.1 \mu \mathrm{M}$ EDTA, $75 \mu \mathrm{M}$ NBT, and $2 \mu \mathrm{M}$ riboflavin). The mixture was illuminated with a $20-\mathrm{W}$ bulb for $10 \mathrm{~min}$. The same mixture was used for the control, but without the enzyme extract, and maintained in the dark. The absorbance readings were made at $560 \mathrm{~nm}$, and one SOD unit was defined as the amount of enzymes capable of inhibiting NBT photoreduction by $50 \%$ under the assay conditions.

Catalase activity (CAT, EC 1.11.1.6) was determined by the consumption of $\mathrm{H}_{2} \mathrm{O}_{2}$ at $240 \mathrm{~nm}$ for $3 \mathrm{~min}$. The reaction mixture was incubated at $28^{\circ} \mathrm{C}$ and was constituted of $25 \mu$ L enzyme extract and $0.975 \mathrm{~mL}$ reaction medium containing $50 \mathrm{mM}$ potassium phosphate buffer ( $\mathrm{pH} 7.0$ ) and $12.5 \mathrm{mM} \mathrm{H}_{2} \mathrm{O}_{2}$. The molar extinction coefficient used was $36 \mathrm{mM}^{-1} \mathrm{~cm}^{-1}$ ) (Havir and Mchale, 1987).

Ascorbate peroxidase activity (APX, EC 1.11.1.11) was determined by measuring the oxidation of ascorbate at $290 \mathrm{~nm}$ for $3 \mathrm{~min}$. The reaction mixture was incubated at $28^{\circ} \mathrm{C}$ and was composed of $60 \mu \mathrm{L}$ enzyme extract and $0.94 \mathrm{~mL}$ reaction mixture containing $50 \mathrm{mM}$ potassium phosphate buffer ( $\mathrm{pH} 7.0$ ), $1 \mathrm{mM} \mathrm{H}_{2} \mathrm{O}_{2}, 0.8 \mathrm{mM}$ L-ascorbic acid, and distilled water. The molar extinction coefficient used was $2.8 \mathrm{mM}^{-1} \mathrm{~cm}^{-1}$ (Nakano and Asada, 1981).

Samples containing $250 \mathrm{mg}$ of root tissue were macerated in liquid nitrogen with 20\% PVPP, homogenized in $5 \mathrm{~mL}$ $0.1 \%$ trichloroacetic acid (TCA), and subsequently centrifuged at $10,000 \times g$ for $10 \mathrm{~min}$ at $4{ }^{\circ} \mathrm{C}$. The supernatant was used to determine the content of hydrogen peroxide $\left(\mathrm{H}_{2} \mathrm{O}_{2}\right)$ and MDA.

$\mathrm{H}_{2} \mathrm{O}_{2}$ content was measured using a spectrophotometer, according to Alexieva et al. (2001). The reaction mixture consisted of $0.5 \mathrm{~mL}$ supernatant extract and $0.5 \mathrm{~mL} 100 \mathrm{mM}$ potassium phosphate buffer ( $\mathrm{pH} 7.0$ ) with $2 \mathrm{~mL} 1 \mathrm{M}$ potassium iodine (KI). The reaction was developed for $1 \mathrm{~h}$ in the dark and absorbance was measured at $390 \mathrm{~nm}$. Concentration of $\mathrm{H}_{2} \mathrm{O}_{2}$ was calculated using a standard curve.

\subsection{Data analysis}

Data were tested for normality by Shapiro-Wilk and for homoscedasticity by the Levine test, and were found to meet the criteria. To compare the characteristics between flooded and nonflooded plants we used the $F$ Test at a 0.05 significance level $(P \leq 0.05)$, using Sisvar software, version 4.3 (Federal University of Lavras, Lavras, Brazil). Means were calculated for all the parameters \pm standard errors (SE).

\section{Results}

\subsection{Physiological responses}

There was no difference between the two treatments in terms of total soluble sugars for the seedlings harvested at 8, 16, 40 and 55 days. However, at 70 and 90 days, the flooded seedlings showed a significant increase in total soluble sugars (Fig. 1A). Starch content was statistically significant only at 90 days, with consumption being noted (decrease) in the flooded seedlings (Fig. 1B). There was no difference between the two treatments at any of the harvesting times in terms of total amino acids present in the roots (Fig. 1C).

\subsection{Morphoanatomical responses}

All the plants were still alive after 90 days under flooded conditions. Hypertrophied lenticels were observed on the basal region of the stem (Fig. 2A and B) and the roots were characteristically dark from flooding stress (Fig. 2A). No adventitious roots were observed. Flooded plants, when compared to non-flooded plants, presented a drastic decrease in their root length (57.6\%), root superficial area (51\%), root volume (42.85\% decrease), and numbers of root tips (61.85\% decrease) (Table 1 and Fig. $2 \mathrm{~A}$ ). Plants that 


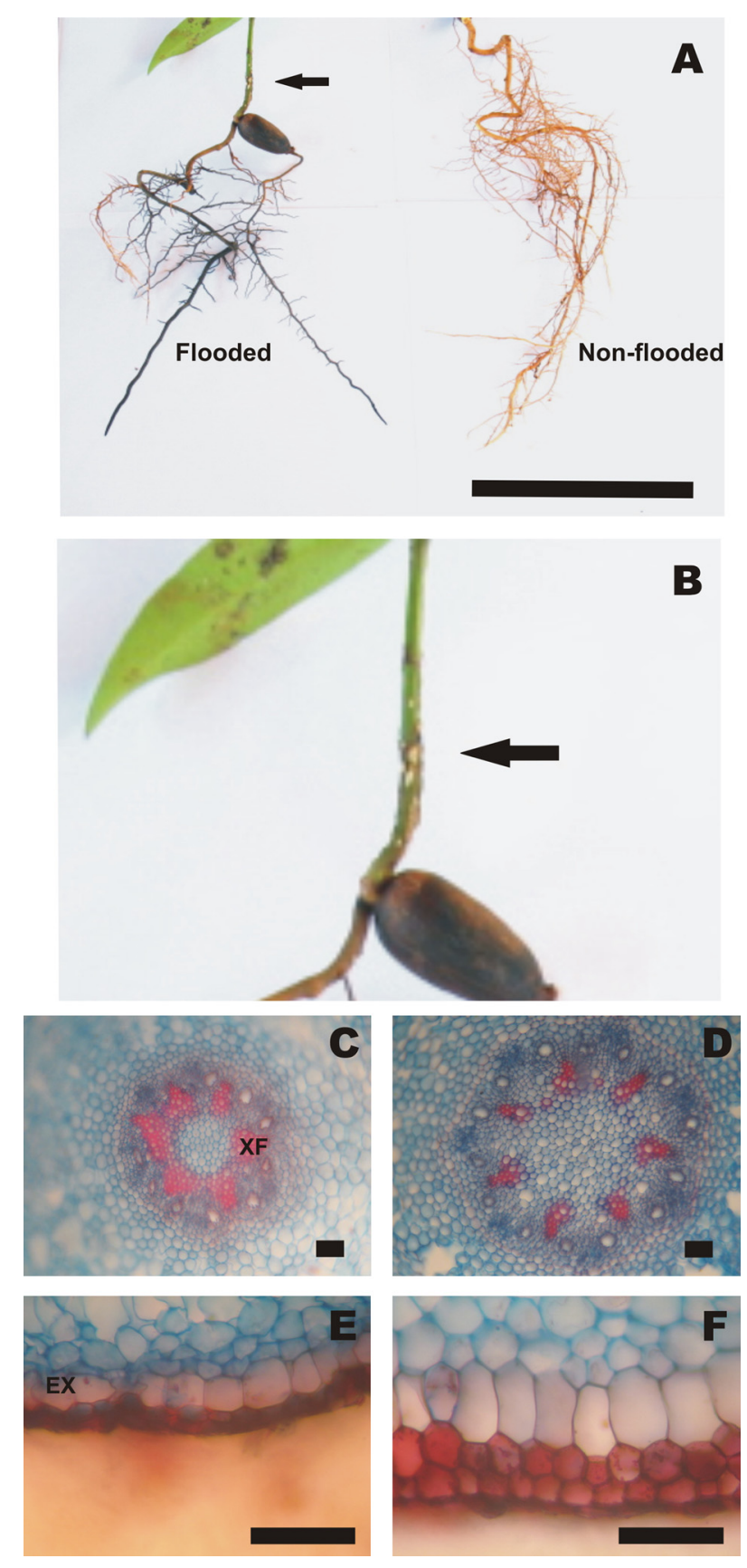

Fig. 2. Morphology and anatomy of G. brasiliensis seedlings. (A) Roots of flooded and non-flooded seedlings, arrow indicates the location of hypertrophied lenticels; (B) amplification of the stem base, arrow indicates the location of the hypertrophied lenticels; (C) photomicrograph of the vascular cylinder of non-flooded roots; (D) photomicrograph of the vascular cylinder of flooded roots; (E) photomicrographs of the exodermis of non-flooded roots and $(F)$ photomicrograph of the exodermis of flooded roots. $X F=$ xylem fibers; $E X=$ exodermis. Bar in $(A)=5 \mathrm{~cm}$; bar in $(C),(D),(E)$ and $(F)=100 \mu \mathrm{m}$.

experienced flooding significantly increased their root medium diameter (Table 1 ).

As far as morphological and dry mass data is concerned, we observed thinnest roots for $G$. brasiliensis under flooding conditions (Table 1). There was no difference between the treatments in terms of root tissue density and specific root length (Table 1 ).

Flooding decreased seedling dry mass production. This decrease was statistically significant for root dry mass (36.3\% decrease), dry leaf mass (44.44\% decrease), and shoot dry mass (35.7\% decrease)
Table 1

Root morphology, dry weight attributes, and root anatomy of flooded and nonflooded $G$. brasiliensis seedlings over time (90 days).

\begin{tabular}{lcc}
\hline Characteristics/treatments & Non-flooded & Flooded \\
\hline Root length $(\mathrm{mm})$ & $6943 \pm 540^{*}$ & $2942 \pm 210$ \\
Root surface area $\left(\mathrm{mm}^{2}\right)$ & $15,580 \pm 1100^{*}$ & $7630 \pm 600$ \\
Root volume $\left(\mathrm{mm}^{3}\right)$ & $2800 \pm 200^{*}$ & $1600 \pm 130$ \\
Average root diameter $(\mathrm{mm})$ & $0.72 \pm 0.02^{*}$ & $0.83 \pm 0.03$ \\
Numbers of root tips & $1434 \pm 166^{*}$ & $547 \pm 78$ \\
Specific root length $\left(\mathrm{mm} \mathrm{g}^{-1}\right)$ & $6280 \pm 550$ & $4533 \pm 650$ \\
Root thinness $\left(\mathrm{mm} \mathrm{mm}^{-3}\right)$ & $2.49 \pm 0.18^{*}$ & $1.93 \pm 0.19$ \\
Root tissue density $\left(\mathrm{g} \mathrm{mm}^{-3}\right)$ & $410 \pm 20$ & $450 \pm 30$ \\
Root dry mass $(\mathrm{g})$ & $1.13 \pm 0.07^{*}$ & $0.72 \pm 0.07$ \\
Stem dry mass $(\mathrm{g})$ & $0.42 \pm 0.03$ & $0.40 \pm 0.04$ \\
Leaf dry mass $(\mathrm{g})$ & $0.9 \pm 0.05^{*}$ & $0.5 \pm 0.04$ \\
Shoot dry mass $(\mathrm{g})$ & $1.4 \pm 0.07^{*}$ & $0.9 \pm 0.08$ \\
Root $/$ shoot ratio & $0.865 \pm 0.06$ & $0.861 \pm 0.11$ \\
Cortex width $(\mu \mathrm{m})$ & $147.6 \pm 7.2$ & $160.9 \pm 10.6$ \\
Exodermis width $(\mu \mathrm{m})$ & $85.6 \pm 3.8^{*}$ & $112.7 \pm 4.7$ \\
PA $(\%)$ & $0.06 \pm 0.02$ & $1.5 \pm 0.6$ \\
Phloem width $(\mu \mathrm{m})$ & $153.0 \pm 17.8^{*}$ & $189.7 \pm 24.9$ \\
Xylem number $(\mu \mathrm{m})$ & $5.4 \pm 0.3^{*}$ & $7.1 \pm 0.7$ \\
Xylem fibers area $\left(\mathrm{mm}{ }^{2}\right)$ & $362.6 \pm 61.8^{*}$ & $165.5 \pm 36.5$ \\
\hline
\end{tabular}

Means \pm SE, $n=10$.

Indicates statistically significant results at $p \leq 0.05$. $\mathrm{PA}=$ proportion occupied by the aerenchyma in the cortex.

(Table 1). No significant difference was observed between the treatments in terms of stem dry mass and root/shoot ratio.

There was no difference between flooded and non-flooded roots regarding length, surface area, and volume distributed through different root diameter classes (Fig. 3). In general, the root system of non-flooded seedlings of $G$. brasiliensis was dominated by thindiameter roots with longer length, larger surface area and higher volume of thinner roots. Roots of flooded seedlings, on the other hand, presented lower values for these parameters for both thin and large diameter roots (Fig. 3).

No difference was observed for cortex width between flooded and non-flooded seedlings (Table 1 ). However, significant difference was observed for exodermis width between the two types of treatments. With flooding, the exodermis increased in width by $23.70 \%$ in relation to non-flooded seedlings (Table 1; Fig. 2E and F). No statistical differences were detected for aerenchyma proportion in root cortex for flooded and no flooded treatments (Table 1). Regarding phloem width, flooded treatment lead to a significant increase in its width (Table 1). Similarly, an increase was observed for xylem vessel number in the roots of flooded seedlings (Table 1). In terms of area of xylem fibers, non-flooded seedlings showed significantly higher means (Table 1; Fig. 2C and D).

\subsection{Antioxidant responses}

Superoxide dismutase (SOD) activity was significantly higher in roots of flooded seedlings throughout the experiment, with a peak of activity at 90 days (Fig. 4A). On the eighth day of flooding, ascorbate peroxidase (APX) activity was equal in both flooded and non-flooded treatments. Significant increase in activity was observed after 70 and 90 days of flooding (Fig. 4B). Catalase activity (CAT) was significant only after 70 and 90 days of flooding (Fig. 4C).

Hydrogen peroxide $\left(\mathrm{H}_{2} \mathrm{O}_{2}\right)$ content varied throughout the experiment, with a significant increase after 40 and 55 days of flooding, followed by a drastic decrease in the mean values after that, with the two treatments having similar values at the end of the experimental period ( 70 and 90 days) (Fig. 4D). 


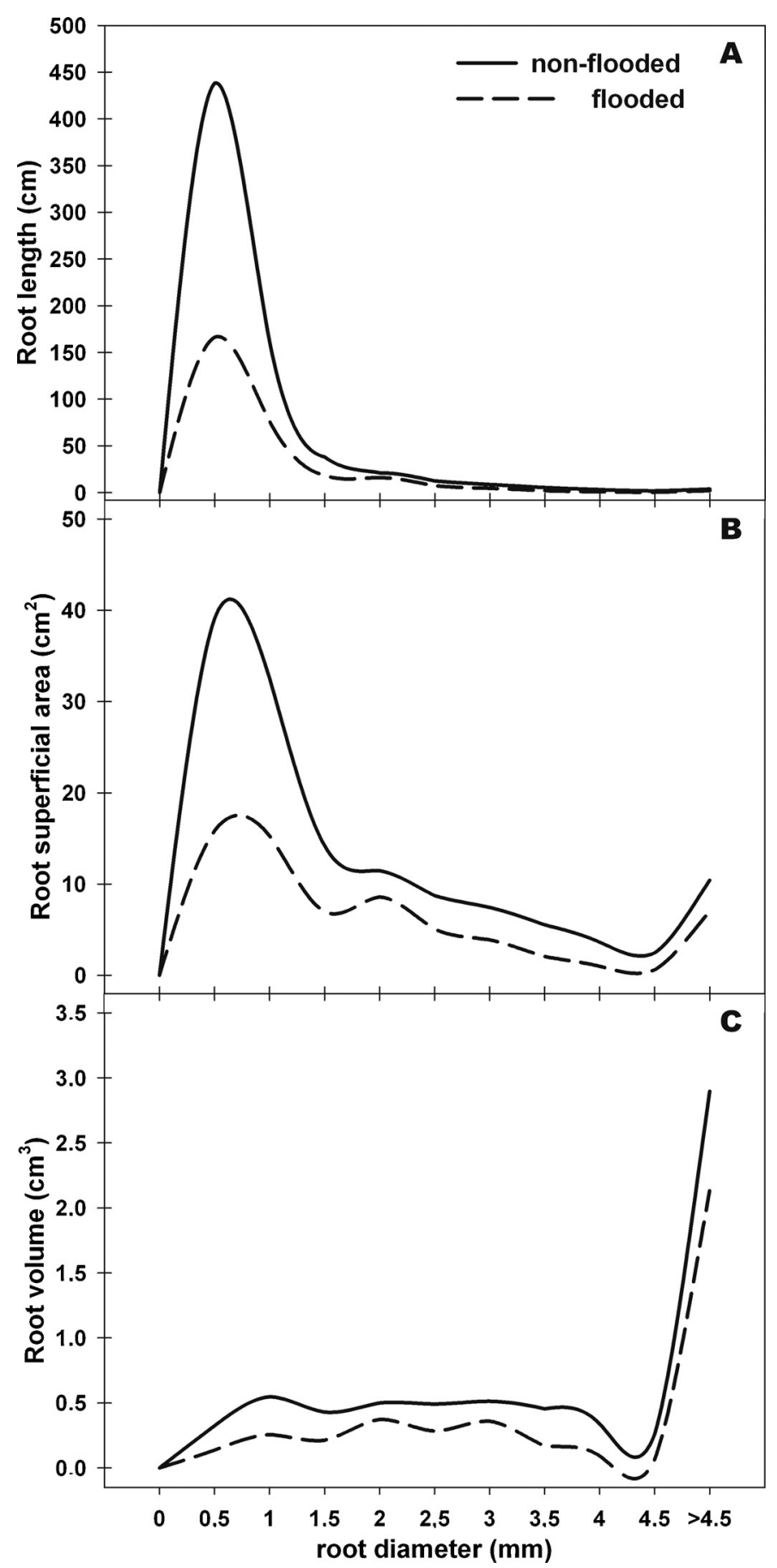

Fig. 3. Means of ten replicates of (A) root length, (B) root superficial area, (C) root volume distributed by diameter classes of roots of flooded and non-flooded G. brasiliensis seedlings (after 90 days of flooding).

\section{Discussion}

No differences were observed between the two treatments in terms of total sugars or starch content until the 55th day of flooding. This low variation in sugar reserve accumulated in roots demonstrates the capacity of $G$. brasiliensis seedlings to tolerate stress through diminished sugar consumption, as the lack of oxygen induces a shift from aerobic respiration to fermentation (Sairam et al., 2008). Continuous supply of fermentable sugars to roots is considered to be critical for long-term survival of plants under flooding (Jackson and Drew, 1984). Flooding did not cause drastic protein degradation, as no change was observed in amino acid content. An increase in amino acid content can result from protein degradation due to oxygen deficiency. It is well known that proteins can undergo hydrolysis, freeing amino acids that, in turn, could be interconverted through the action of transaminase enzymes induced by anoxia, giving rise to new types of amino acids (Sousa and Sodek, 2002).

G. brasiliensis seedlings did not present adventitious roots. However, still regarding root aeration, hypertrophied lenticels were observed at the bases of the stems of flooded G. brasiliensis seedlings. They can favor ventilation in these roots, since they are under $\mathrm{O}_{2}$ deficit (Shimamura et al., 2010). The flooded seedlings probably showed low development of thin roots due to their sensitivity to stress conditions, resulting in the inhibition of their development and even death, as reported in other studies (Imada et al., 2008). Regarding root medium diameter, Ryser (2006) noted that larger root diameter could lead to a smaller specific length. Root length of $G$. brasiliensis were slightly smaller on the average but there were no statistically significant alterations in the specific length. According to Eissenstat (1992), longer specific length and longer length of fine roots would be disadvantageous under flooding conditions as they would increase the root surface area, which, according to Sorrel (1994), would lead to a greater loss of oxygen from the roots to the soil. High root tissue density (root with large amount of dead tissue) is one of the characteristics of species occupying high stress environments that lead to a decrease of root specific length (Wahl et al., 2000). Although seedlings grown under flooding conditions had lesser quantities of xylem fibers (dead tissue) no significant alterations of their average root medium diameter were noted.

In spite of the fact that flooded plants showed significantly lower leaf dry mass and shoot dry mass, no difference in the relationship between root dry mass and shoot dry mass was observed. Plants submitted to root flooding could send signals from roots to shoot to induce stomatal closure (Else et al., 2009). When stomata close, gas exchange is interrupted as well as photosynthesis, and biomass production tends to diminish. Ferreira et al. (2009) observed a strong decrease in biomass accumulation in Himatanthus sucuuba (Apocynaceae) when exposed to long flooding periods.

There was no difference in cortex width between the two treatments in G. brasiliensis. However, a decrease in cortex width was reported in Cecropia pachystachya (Cecropiaceae) and Caesalpinia peltophoroides (Fabaceae) by Batista et al. (2008) and Henrique et al. (2010), respectively, under flooding conditions.

One of the anatomical characteristics of $G$. brasiliensis that appears to favor flooding tolerance is the presence of a thick layer of hypodermal cells (exodermis). This cell layer prevents radial loss of oxygen to the rhizosphere while increasing longitudinal oxygen diffusion in the root (Colmer, 2003). Additionally, this suberized layer protects against phytotoxin absorption (Soukup et al., 2002) and pathogen exposure (De Simone et al., 2003).

No aerenchyma presence was observed in flooded roots. Santiago and Paoli (2007), studying the effects of flooding on the tree species Guibourtia hymenifolia (Fabaceae), also did not observe the presence of any significant amount of root aerenchyma. Nevertheless, this tissue has frequently been observed in other native Amazon plants (Ferreira et al., 2009; Parolin, 2009). This tissue, which is essentially composed of air chambers, facilitates gas transfer between aerial organs and roots (Bailey-Serres and Voesenek, 2008). Plants growing under flood conditions experience inhibition of photosynthate transport to the roots (Chen et al., 2005). Thicker phloem tissue, as seen in roots of $G$. brasiliensis, may favor flooding tolerance as this tissue would contribute to an increased photosynthate transport from the aerial organs of these plants to their roots (Souza et al., 2009), which experience energy deficit due to their shift to anaerobic metabolism. 


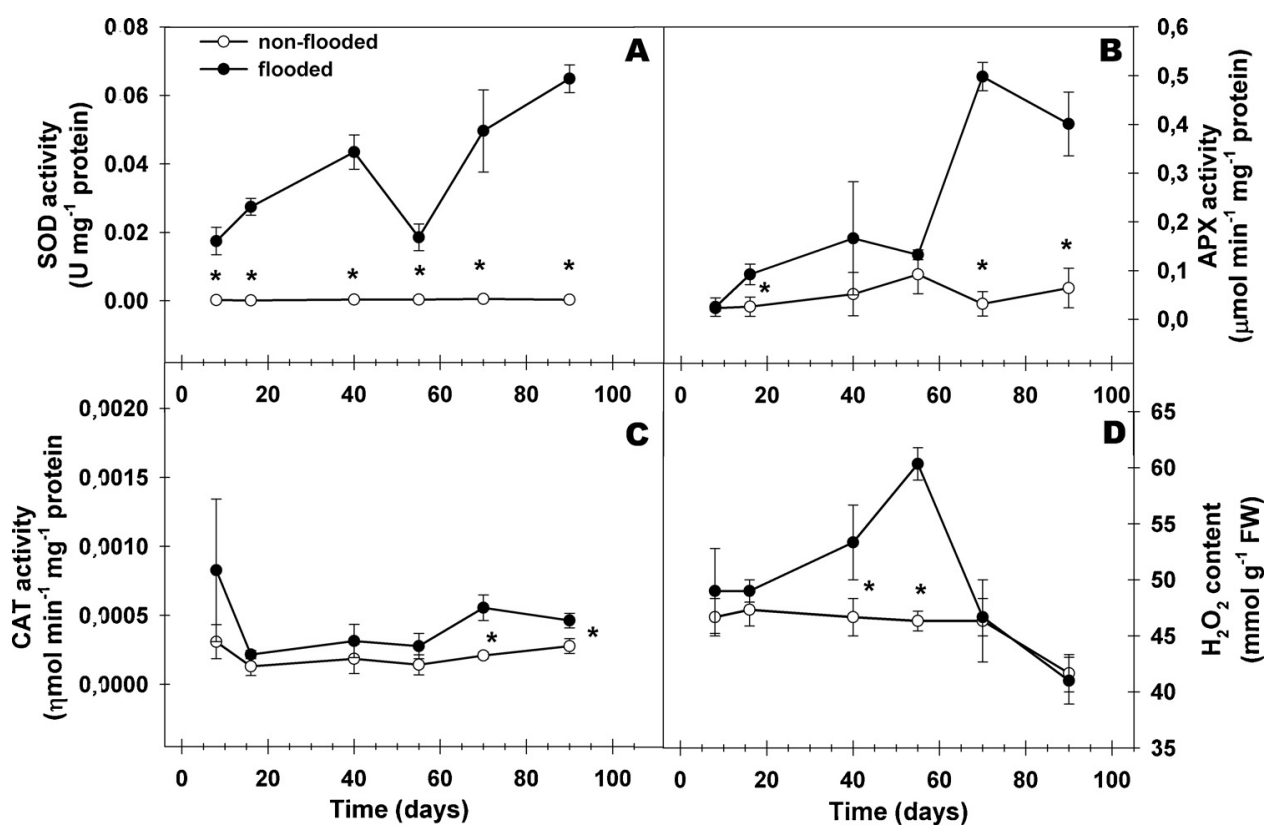

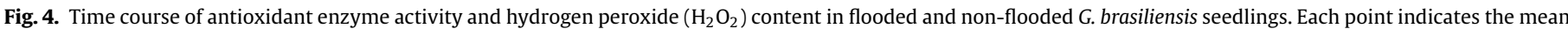

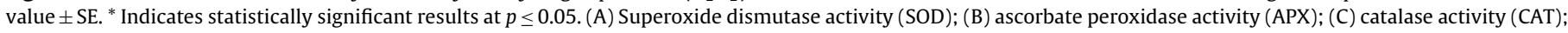
(D) $\mathrm{H}_{2} \mathrm{O}_{2}$ content.

A large xylem vessel number found in the roots of flooded seedlings in the present experiment may be related to a guarantee in the maintenance of water flow, as the ability of roots to absorb water is inhibited by lack of oxygen (Dell'Amico et al., 2001; Tournaire-Roux et al., 2003). Reduction in sclerenchyma tissue (xylem fibers) was observed in flooded roots, which may be relevant as an energy-saving strategy that favors the production of more important tissues (such as phloem, which facilitates seedling survival in flooded environments) (Souza et al., 2010).

In terms of antioxidant enzyme systems, we observed significantly high superoxide dismutase (SOD) activity throughout the experiment, as well as high ascorbate peroxidase (APX) and catalase (CAT) activities in the final assays (after 70 and 90 days) in flooded roots. One form of defense against low oxygen conditions is the expression of enzymes in charge of removing detrimental reactive oxygen species (ROS), (Moller et al., 2007; Karuppanapandian et al., 2011). These results are good indications that, peroxidases of the ascorbate cycle, catalases, and superoxide dismutases are important to preserve the physiological integrity of $G$. brasiliensis seedlings. Regarding hydrogen peroxide $\left(\mathrm{H}_{2} \mathrm{O}_{2}\right)$, an increase was observed in its concentration until the 55th day of root flooding. This increase may have been due to a high SOD activity, which is responsible for transforming singlet oxygen (ROS) into $\mathrm{H}_{2} \mathrm{O}_{2}$. On the other hand, it is possible that the observed increase in APX and CAT activities after 55 days of flooding reduced $\mathrm{H}_{2} \mathrm{O}_{2}$ content.

It can, therefore, be concluded that flooding stress led to a decrease in root length, root superficial area, root volume as well as in biomass attributes of $G$. brasiliensis seedlings. There were significant biochemical and anatomical changes in seedlings of $G$. brasiliensis related to flooding tolerance which favor their survival. Thus these plants can be used for ciliary reforestation of artificial reservoir formed by the construction of dams.

\section{References}

Alexieva, V., Sergiev, I., Mapelli, S., Karanov, E., 2001. The effect of drought and ultraviolet radiation on growth and stress markers in pea and wheat. Plant Cell Environ. 24, 1337-1344

Armstrong, W., Brändle, R., Jackson, M.B., 1994. Mechanisms of flood tolerance in plants. Acta Bot. Neerl. 43, 307-358.
Armstrong, W., Justin, S.H.F.W., Beckett, M.P., Lythe, S., 1991. Root adaptation to soil waterlogging. Aquat. Bot. 39, 57-73.

Bailey-Serres, J., Fukao, T., Gibbs, D.J., Holdsworth, M.J., Lee, S.C., Licausi, F., Perata, P., Voesenek, L.A.C.J., van Dongen, J.T., 2012. Making sense of low oxygen sensing. Trends Plant Sci. 17, 129-138.

Bailey-Serres, J., Voesenek, L.A.C.J., 2008. Flooding stress: acclimations and genetic diversity. Ann. Rev. Plant Biol. 59, 313-339.

Batista, C.U.N., Medri, M.E., Bianchini, E., Medri, C., Pimenta, J.A., 2008. Tolerância à inundação de Cecropia pachystachya Trec. (Cecropiaceae): aspectos ecofisiológicos e morfoanatômicos. Acta Bot. Bras. 22, 91-98.

Bouma, T.J., Nielsen, K.L., Koutstaal, B.A.S., 2000. Sample preparation and scanning protocol for computerized analysis of root length and diameter. Plant Soil 218 $185-196$.

Bradford, M., 1976. Rapid and quantitative method for quantization of microgram quantities of protein utilizing the principle of protein-dye binding. Ann. Biochem. 72, 252-284.

Chen, H., Qualls, R.G., Balk, R.R., 2005. Effect of soil flooding on photosynthesis carbohydrate partitioning and nutrient uptake in the invasive exotic Lepidum latifolium. Aquat. Bot. 82, 250-268.

Colmer, T.D., 2003. Long-distance transport of gases in plants a perspective on internal aeration and radial oxygen loss from roots. Plant Cell Environ. 26, 17-36.

Colmer, T.D., Voesenek, L.A.C.J., 2009. Flooding tolerance: suites of plant traits in variable environments. Funct. Ecol. 36, 665-681.

De Simone, O., Haase, K., Muller, E., Junk, W.J., Hartmann, K., Schreiber, L., Schmidt W., 2003. Apoplasmic barriers and oxygen transport properties of hypodermal cell walls in roots from four Amazonian tree species. Plant Physiol. 132 206-217.

Dell'Amico, J., Torrecillas, A., Rodrigues, P., Morales, D., Sanche-Blanco, M.J., 2001 Differences in the effects of flooding the soil early and late in the photoperiod on the water relations of pot-grown tomato plants. Plant Sci. 160, 481-487.

Duarte, H.M., Gebler, A., Scarano, F.R., Franco, A.C., Mattos, E.A., Nahm, M., Rennenberg, H., Rodrigues, P.J.F.P., Zaluar, H.L., Luttge, U., 2005. Ecophysiology of six selected shrub species in different plant communities at the periphery of the Atlantic Forest of SE-Brazil. Flora 200, 456-476.

Eissenstat, D.M., 1992. Costs and benefits of constructing roots of small diameter. J. Plant Nutr. 15, 763-782.

Else, M.A., Janowiak, F., Atkinson, C.J., Jackson, M.B., 2009. Root signals and stomatal closure in relation to photosynthesis, chlorophyll a fluorescence and adventitious rooting of flooded tomato plants. Ann. Bot. 103, 313-323.

Ferreira, C.S., Piedade, M.T.F., Franco, A.C., Gonçalves, J.F.C., Junk, W.J., 2009. Adaptative strategies to tolerate prolonged flooding in seedlings of floodplain and upland populations of Himatanthus sucuuba, a Central Amazon tree. Aquat. Bot. 90, 246-252.

Giannopolitis, C.N., Ries, S.K., 1977. Superoxide dismutases: I., occurrence in higher plants. Plant Physiol. 59, 309-314.

Gontijo, V.S., Souza, T.C., Rosa, I.A., Soares, M.G., Silva, M.A., Vilegas, W., Viegas Júnior, C., Santos, M.H., 2012. Isolation and evaluation of the antioxidant activity of phenolic constituents of the Garcinia brasiliensis epicarp. Food Chem. 132, $1230-1235$.

Havir, E.A., Mchale, N.A., 1987. Biochemical and developmental characterization of multiple forms of catalase in tobacco leaves. Plant Physiol. 84, 450-455. 
Henrique, P.C., Alves, J.D., Goulart, P.F.P., Deuner, S., Silveira, N.M., Zanandrea, I., Castro, E.M., 2010. Physiological and anatomical characteristics of Sibipiruna plants under hipoxia. Ciênc. Rural 40, 70-76.

Horchani, F., Aloui, A., Brouquisse, R., Aschi-Smiti, S., 2008. Physiological responses of tomato plants (Solanum lycopersicum) as affected by root hypoxia. J. Agron. Crop Sci. 197, 297-303.

Imada, S., Yamanaka, N., Tamai, S., 2008. Water table depth effects Populus alba fine root growth and whole plant biomass. Funct. Ecol. 22, 1018-1026.

Jackson, M.B., Colmer, T.D., 2005. Response and adaptation by plants to flooding stress. Ann. Bot. 96, 501-505.

Jackson, M.B., Drew, M.C., 1984. Effects of flooding on growth and metabolism of herbaceous plants. In: Kozlowski, T. (Ed.), Flooding and Plant Growth. Academic Press, New York, NY, USA, pp. 47-128.

Jackson, M.B., Ishizawa, K., Ito, O., 2009. Evolution and mechanisms of plant tolerance to flooding stress. Ann. Bot. 103, 137-142.

Karuppanapandian, T., Moon, J.-C., Kim, C., Manoharan, K., Kim, W., 2011. Reactive oxygen species in plants: their generation, signal transduction, and scavenging mechanisms. Aust. J. Crop Sci. 5, 709-725.

Martins, F.T., Doriguetto, A.C., Souza, T.C., Souza, K.R.D., Santos, M.H., Moreira, M.E.C., Barbosa, L.C.A.B., 2008. Composition, and anti-inflammatory and antioxidant activities of the volatile oil from the fruit peel of Garcinia brasiliensis. Chem. Biodivers. 5, 251-258.

Mitler, R., 2002. Oxidative stress, antioxiants and stress tolerance. Trends Plant. Sci. 7, 405-410.

Moller, I.M., Jensen, P.E., Hansson, A., 2007. Oxidative modifications to cellular components in plants. Ann. Rev. Plant Biol. 58, 459-481.

Nakano, Y., Asada, K., 1981. Hydrogen peroxide is scavenged by ascorbatespecific peroxidase in spinach chloroplasts. Plant Cell Physiol. 22, $867-880$.

Nelson, N., 1944. A photometric adaptation of Somogyi method for determination of glucose. J. Biol. Chem. 135, 136-175.

Oliveira-Wittmann, A., 2007. Conteúdo de tococromanóis em espécies arbóreas de várzea da Amazônia Central. INPA/UFAM Manaus, Brazil (PhD Thesis).

Oliveira, V.C., Joly, C.A., 2010. Flooding tolerance of Calophyllum brasiliense Camb. (Clusiaceae): morphological, physiological and growth responses. Trees 24, 185-193.
Parolin, P., 2009. Submerged in darkness: adaptations to prolonged submergence by wood species of the Amazonian floodplains. Ann. Bot. 103, 359-376.

Ryser, P., 2006. The mysterious root length. Plant Soil 286, 1-6.

Sairam, R.K., Kumutha, D., Ezhilmathi, K., Deshmukh, P.S., Srivastava, G.C., 2008 Physiology and biochemistry of waterlogging tolerance in plants. Biol. Plant 52, 401-412.

Santiago, E.F., Paoli, A.A.S., 2007. Morphologycal responses in Guibourtia hymenifolia (Moric) J. Leonard (Fabaceae) and Genipa Americana L. (Rubiaceae), submitted to nutritional deficit and flooding stress. Rev. Bras. Bot. 30, 129-138.

Shimamura, S., Yamamoto, R., Nakamura, T., Shimada, S., Komatsu, S., 2010. Stem hypertrophied lenticels and secondary aerenchyma enable oxygen transport to roots of soybean in flooded soil. Ann. Bot. 106, 277-284.

Silva, S., Soares, A.M., Oliveira, L.E.M., Magalhães, P.C., 2001. Physiologycal responses of promising grasses for sideline revegetation of hydroelectrical reservoirs subjected to water deficit. Cienc. Agrotec. 25, 124-133.

Soukup, A., Votrubová, O., Ciskova, I.I., 2002. Development of anatomical structure of roots of Phragmites australis. New Phytol. 153, 277-287.

Sousa, C.A.F., Sodek, L., 2002. Respostas metabólicas de plantas a deficiência de oxigênio. Braz. J. Plant Physiol. 14, 83-94.

Souza, T.C., Castro, E.M., Pereira, F.J., Parentoni, S.N., Magalhães, P.C., 2009. Morphoanatomical characterization of root in recurrent selection cycles for flood tolerance of maize (Zea mays L.). Plant Soil Environ. 55, 504-510.

Souza, T.C., Magalhães, P.C., Pereira, F.P., Castro, E.M., Silva Junior, J.M., Parentoni, S.N., 2010. Leaf plasticity in successive selection cycles of 'Saracura' maize in response to periodic soil flooding. Pesqui. Agropec. Bras. 45, 16-24.

Sorrel, B.K., 1994. Airspace structure and mathematical modeling of oxygen diffusion, aeration and anoxia in Eleocharis aphacelata R. Br. roots. Aust. J. Marine Fresh. Res. 45, 1529-1541.

Tournaire-Roux, C., Sufka, M., Javot, H., Gout, E., Gerbeau, P., Luu, D.T., Bligny, R., Maurel, C., 2003. Cytosolic pH regulates root water transport during anoxid stress through gating of aquaporins. Nature 425, 393-397.

Wahl, S., Ryser, P., Edwards, P.J., 2000. Root tissue structure is linked to ecological strategies of grasses. New Phytol. 148, 459-471.

Yemm, E.W., Willis, A.J., 1954. The estimation of carbohydrates in plants extracts by anthrone. Biochem. J. 57, 508-514.

Yemm, E.W., Cocking, C., 1954. The determination of amino-acids with ninhydrin. Analyst 80, 209-214. 